\title{
Alkaline phosphatases contribute to uterine receptivity, implantation, decidualization, and defense against bacterial endotoxin in hamsters
}

\author{
Wei Lei, Heidi Nguyen, Naoko Brown, Hua Ni, Tina Kiffer-Moreira', Jeff Reese, \\ José Luis Millán ${ }^{1}$ and Bibhash C Paria \\ Division of Neonatology, Department of Pediatrics, Vanderbilt University Medical Center, 1125 Light Hall, \\ 2215 B. Garland Avenue, Nashville, Tennessee 37232-0656, USA and ${ }^{1}$ Sanford-Burnham Medical Research Institute, \\ Sanford Children's Health Research Center, La Jolla, California 92037, USA
}

Correspondence should be addressed to B C Paria; Email: bc.paria@vanderbilt.edu

\begin{abstract}
Alkaline phosphatase (AP) activity has been demonstrated in the uterus of several species, but its importance in the uterus, in general and during pregnancy, is yet to be revealed. In this study, we focused on identifying AP isozyme types and their hormonal regulation, cell type, and event-specific expression and possible functions in the hamster uterus during the cycle and early pregnancy. Our RT-PCR and in situ hybridization studies demonstrated that among the known Akp2, Akp3, Akp5, and Akp6 murine AP isozyme genes, hamster uteri express only Akp2 and Akp6; both genes are co-expressed in luminal epithelial cells. Studies in cyclic and ovariectomized hamsters established that while progesterone $\left(P_{4}\right)$ is the major uterine $A k p 2$ inducer, both $\mathbf{P}_{4}$ and estrogen are strong Akp6 regulators. Studies in preimplantation uteri showed induction of both genes and the activity of their encoded isozymes in luminal epithelial cells during uterine receptivity. However, at the beginning of implantation, Akp2 showed reduced expression in luminal epithelial cells surrounding the implanted embryo. By contrast, expression of $A k p 6$ and its isozyme was maintained in luminal epithelial cells adjacent to, but not away from, the implanted embryo. Following implantation, stromal transformation to decidua was associated with induced expressions of only Akp2 and its isozyme. We next demonstrated that uterine APs dephosphorylate and detoxify endotoxin lipopolysaccharide at their sites of production and activity. Taken together, our findings suggest that uterine APs contribute to uterine receptivity, implantation, and decidualization in addition to their role in protection of the uterus and pregnancy against bacterial infection.
\end{abstract}

Reproduction (2013) 146 419-432

\section{Introduction}

The uterus enters into the receptive state following mating to support blastocyst attachment, which then induces the decidualization program in rodents. Defects in uterine receptivity, implantation, and decidualization are known causes of compromised fertility in females (van Mourik et al. 2009), but details of the uterine molecular reprogramming involved in these processes have not yet been established. The uterus is also susceptible to bacterial infection and intrauterine infection is a leading cause of pelvic inflammatory disease, endometritis, infertility, subfertility, early pregnancy loss, fetal defects, and preterm birth (Adamson \& Baker 2003, Goldenberg et al. 2008, Aisemberg et al. 2010, Keelan 2011, Sweet 2012). However, the molecules that the uterus uses to neutralize the toxicity of bacterial toxins (endotoxins) in general and during pregnancy remain unidentified.

Alkaline phosphatase (AP, EC 3.1.3.1) is an ancient enzyme that was thought to have insignificant physiological roles as it hydrolyzes phosphate esters at high alkaline $\mathrm{pH}$ (Millan 1990). However, this perception has changed, and a new chapter of AP physiology has emerged with the following findings: i) this enzyme can act at very close to neutral pH (Millan 2006); ii) genetic ablation of AP isozymes in mice revealed distinct phenotypes such as skeletal defects in Akp2-null mice (Waymire et al. 1995), altered fatty acid transport in the gut in Akp3-null mice (Narisawa et al. 2003, Nakano et al. 2007), delayed parturition, and reduced litter size in Akp5-null mice (Dehghani et al. 2000); and iii) AP may contribute to host defense against pathogeninduced inflammation (Poelstra et al. 1997a, 1997b, 
Koyama et al. 2002, Goldberg et al. 2008, Malo et al. 2010, Ramasamy et al. 2011). AP isozymes are membrane-bound molecules that are divided into two groups, tissue-nonspecific AP (TNAP) and tissue-specific APs (TSAPs). TNAP, which is also commonly known as the kidney/bone/liver isozyme, is encoded by the $A k p 2$ (a.k.a. Alpl) gene in mice. TSAPs in mice include duodenum-specific intestinal AP (dIAP) that is encoded by the $A k p 3$ gene, global IAP (gIAP) that is encoded by the Akp6 gene, and embryonic AP (EAP) that is encoded by the Akp5 gene (Millan 2006, Narisawa et al. 2007). AP activity studies in the mouse and rat uteri during early pregnancy have demonstrated a correlation of APactivity with decidua formation as its activity is strong in decidual stromal cells following implantation (Finn \& Hinchliffe 1964, Manning et al. 1969, Murdoch et al. 1978, Pollard et al. 1990, Bucci \& Murphy 1995). However, its physiological role in the uterus of any species prior to and during pregnancy has not been assigned. To our knowledge, neither the uterine AP gene(s) nor the AP activity pattern with respect to uterine changes during the cycle and early pregnancy has been reported in the hamster, unlike mice and rats in which maternal ovarian estrogen secretion is required for initiation of implantation, but similar to guinea pigs, rabbits, pigs, horses, monkeys, and humans in which AP supports blastocyst implantation only in the progesterone $\left(\mathrm{P}_{4}\right)$-primed uterus (Reese et al. 2008). Thus, an attempt was made to test a hypothesis that AP isozymes expressed in the hamster uterus, showing cyclic, hormonal, and pregnancy-related changes, are involved in regulation of the processes of implantation, decidualization, and detoxification of endotoxin.

\section{Materials and methods Animals}

Adult virgin male and female golden hamsters (Mesocricetus auratus; 8-10 weeks-old) were purchased from Charles River Laboratory (Wilmington, MA, USA) and housed in a $14 \mathrm{~h}$ light:10 h darkness cycle in the Laboratory Animal Facility of the Vanderbilt University Medical Center with ad libitum access to water and food according to the Institutional Guidelines on the Care and Use of Laboratory Animals. All experimental animal procedures were approved by the Vanderbilt University Medical Center Institutional Animal Care and Use Committee.

\section{Uterine tissue collection during the estrous cycle}

The day of vaginal discharge in hamsters is considered as the estrous day (Zhang \& Paria 2006). Cyclic uterine tissues were collected (0800-0900 h) at estrus, metestrus, diestrus, and proestrus. Tissues were instantly frozen in pre-chilled Friendly Freeze'it (Curtin Matheson Scientific, Houston, TX, USA) and stored at $-80^{\circ} \mathrm{C}$.

\section{Uterine tissue collection during early pregnancy of hamsters}

Female hamsters were mated with fertile males on the evening of proestrus. Vaginal secretions were checked the next morning for the presence of sperm, which indicated day 1 of pregnancy (Zhang \& Paria 2006). Whole hamster uteri from days 1 to 3 of pregnancy were collected at 0830-0900 h. Although whole hamster uteri were also collected in the morning of day 4 at $0900 \mathrm{~h}$, implantation sites were collected at $1800 \mathrm{~h}$ on day 4 and $0900 \mathrm{~h}$ on day 5 after an i.v. injection of $1 \%$ Chicago blue B dye solution (Sigma; $0.25 \mathrm{ml}$ 1\% dye in saline) (Zhang \& Paria 2006). On days 6-8 of pregnancy, implantation sites of hamsters showed distinct uterine swelling and were collected without blue dye injection. A part of the liver and small intestine were also obtained. All tissues were immediately frozen and stored at $-80{ }^{\circ} \mathrm{C}$.

\section{Induction of deciduomata by intrauterine silk suture}

A short section of silk suture was placed inside one uterine horn of pregnant hamsters in the morning $(0600 \mathrm{~h})$ of day 4 of pregnancy for the purpose of disturbing normal embryo implantation and induction of deciduomata. The contralateral horns of these animals were not disturbed for normal embryo implantation and decidum formation. Animals were killed on day 6 of pregnancy and inspected for the presence of intermittent implantation sites in the undisturbed uterine horn and the deciduomata in the suture-containing horn. The embryo-induced decidum and suture-induced deciduomata were collected and stored at $-80^{\circ} \mathrm{C}$.

\section{Hamster blastocyst collection}

Pregnant hamsters were killed at $0100 \mathrm{~h}$ on day 4 to recover blastocysts from their uteri. Hamster blastocysts were washed thoroughly in hamster embryo culture medium-2 to eliminate uterine cell contamination (Wang et al. 2002). Twenty to 25 blastocysts were grouped in a sterile 1.5 microcentrifuge tube, frozen, and stored at $-80^{\circ} \mathrm{C}$.

\section{Uterine tissue collection from ovariectomized $P_{4^{-}}$and estradiol-17 $\beta$-treated hamsters}

Female hamsters were ovariectomized regardless of their stage of the cycle and rested for at least 10-15 days to eliminate circulating steroids (Zhang \& Paria 2006). Animals then received a single injection (s.c.) of sesame seed oil as the vehicle (0.2 $\mathrm{ml} /$ hamster), $\mathrm{P}_{4}(2 \mathrm{mg} / 0.2 \mathrm{ml} /$ hamster $)$, estradiol- $17 \beta\left(\mathrm{E}_{2}\right)$ ( $1 \mu \mathrm{g} / 0.2 \mathrm{ml} /$ hamster), or $\mathrm{P}_{4}$ plus $\mathrm{E}_{2}$. Control hamsters injected with vehicle were killed 6, 12, and $24 \mathrm{~h}$ later. All steroid-treated hamsters were also killed 6, 12, and $24 \mathrm{~h}$ after steroid injection. Uteri were immediately frozen and stored at $-80{ }^{\circ} \mathrm{C}$.

\section{Total RNA extraction}

Total RNA from the uterus, liver, and small intestine was extracted using TRIZOL reagent (Invitrogen Life Technologies) according to the manufacturer's instruction. The isolated RNAs 
were treated with DNase 1 for $30 \mathrm{~min}$ at $37^{\circ} \mathrm{C}$ followed by phenol-chloroform extraction. To precipitate RNA, an ammonium acetate solution was added to the aqueous RNA solution to a concentration of $2.5 \mathrm{M}$. Then $2.5 \mathrm{vol}$. of pre-chilled ethanol was added and the solution was chilled for at least $2 \mathrm{~h}$ at $-20{ }^{\circ} \mathrm{C}$. The precipitated RNA was separated by centrifugation, washed with $75 \%$ ethanol, and dissolved in RNase-free water (Wang et al. 2002). Total RNA from blastocysts was extracted as described previously (Wang et al. 2002).

\section{RT-PCR}

DNase-treated total RNAs were subjected to cDNA synthesis by RT using oligo(dT) primers according to the manufacturer's instruction (Invitrogen). PCR was performed using sense and antisense primers from mouse Akp2, Akp3, Akp5, Akp6, and a housekeeping gene $R p / 7$. Primer sequences were as follows: Akp2 (sense: 5'-GTG GAT ACA CCC CCC GGG GC-3'; antisense: 5'-GGT CAA GGT TGG CCC CAA TGC A-3'), Akp3 (sense: 5'-GCT GGA ACC CCA GAC CCC GAG-3'; antisense: 5'-GGC CCT CTC GAT GGC TAA GTC G-3'); Akp5 (sense: 5'-CGC ACC AGT GAG CAG GAC ACG-3'; antisense: 5'-GCC CGG GCT CAC TGC ACT GC-3'), Akp6 (sense: $5^{\prime}$-AGA CAG GTC CCA GAC AGC G-3'; antisense: $5^{\prime}$ CCA CCG AGG ATC ACA TCA A-3'); and Rpl7 (sense: $5^{\prime}$-TGA ATG GAG TAA TCC CAA AG-3'; antisense: $5^{\prime}$-CAA GAG ACC GAG CAA TCA AG- $\left.3^{\prime}\right)$. The $A k p 2, A k p 3$, and $A k p 5$ primer pairs were used previously by Hahnel et al. (1990), and Rpl7 primer pairs were used by Wang et al. (2002). Primers for Akp6 were designed from GenBank accession number NM_001081082. PCRs were performed under the following conditions: initial denaturation at $94{ }^{\circ} \mathrm{C}$ for $5 \mathrm{~min}, 40$ cycles consisting of $94{ }^{\circ} \mathrm{C}$ for $30 \mathrm{~s}, 60{ }^{\circ} \mathrm{C}$ for $30 \mathrm{~s}, 72{ }^{\circ} \mathrm{C}$ for $30 \mathrm{~s}$, and a final extension step at $72{ }^{\circ} \mathrm{C}$ for $10 \mathrm{~min}$. The reactions were carried out in a final volume of $20 \mu \mathrm{l}$. PCR-generated products were resolved electrophoretically (1.2\% agarose gel) along with 100-bp ladder, stained with ethidium bromide, and photographed. Only Rp/7 positive samples were used for $A k p 2, A k p 3, A k p 5$ and $A k p 6$ expression studies. The PCR products were cloned into pCR-II-TOPO cloning vector using a TOPO TA Cloning kit, version K2 (Invitrogen). Nucleotide sequencing of these clones were performed to verify the identity and orientation of each clone. The GenBank accession numbers for the hamster Akp2 and Akp6 are JQ_928734 and JQ_966128 respectively.

\section{Real-time PCR}

DNase-treated total RNAs $(1 \mu \mathrm{g})$ were reverse transcribed as described earlier in the Materials and Methods section for RT-PCR. One microliter of the first strand was amplified in $25 \mu \mathrm{l}$ total volume in an iCycler (Bio-Rad Laboratories, Inc.) using iQ SYBER Green Supermix (cat. \# 170-8880; Bio-Rad). The following PCR protocol was used: $95^{\circ} \mathrm{C}$ for 3 min followed by 45 cycles of $95{ }^{\circ} \mathrm{C}$ for $10 \mathrm{~s}$ and $55^{\circ} \mathrm{C}$ for $30 \mathrm{~s}$. All reactions were run in triplicates. The quantification was performed by the iQ 5 Standard Edition Optical System Version 2.0. Data from real-time PCR analysis were normalized to hypoxanthine phosphoribosyltransferase 1 (Hprt (Hprt1)) expression for analysis and results transformed to $2^{-\Delta \Delta C t}$ with the oil-treated control groups as the reference for clarity of presentation. Hamster-specific Akp2 and Akp6 primer sequences were as follows: Akp2 (GenBank accession number JQ_928734; sense: 5'-GGC TAC AAG GTG GTG GAT GG-3'; antisense: 5'-GCA AAG ACT GCC ACA TCT TCC-3'), Akp6 (GenBank accession number JQ_966128; sense: 5'-ACA GCC ACC GCC TAT CTC T-3'; antisense: 5'-GCT TGG CAC GAT ACA TCA CT-3'). Primers used to detect the Hprt gene (GenBank accession number NM_013556; sense: 5'-GCT TGG CAC GATA CAT CAC T-3'; antisense: $5^{\prime}$-CCC TGA AGT ACT CAT TAT AGT CAA GGG CAT-3') were previously used by us (Wang et al. 2011).

\section{RNA probe preparation}

Plasmids bearing hamster Akp2 and Akp6 cDNAs were extracted, purified, and linearized ( $A k p 2$ : Spel/T7 for antisense, EcoRV/SP6 for sense; Akp6: EcoRV/SP6 for antisense, Spel/T7 for sense). For in situ hybridization, ${ }^{35} \mathrm{~S}$-labeled antisense and sense cRNA probes were generated using appropriate RNA polymerases (Wang et al. 2002).

\section{In situ hybridization}

In situ hybridization was performed as described previously by our group (Wang et al. 2002). Briefly, frozen uterine sections were fixed in cold $4 \%$ paraformaldehyde solution in PBS for $15 \mathrm{~min}$ on ice. Following pre-hybridization, sections were hybridized to ${ }^{35} \mathrm{~S}$-labeled antisense probes at $45{ }^{\circ} \mathrm{C}$ for $4 \mathrm{~h}$. Sections hybridized with ${ }^{35} \mathrm{~S}$-labeled sense probes were used as negative control. After hybridization and washing, sections were incubated with RNase A at $37^{\circ} \mathrm{C}$ for 20 min. RNase A-resistant hybrids were detected autoradiography using Kodak NTB-2 liquid emulsion (Eastman Kodak Co.). The slides were then stained with hematoxylin and eosin (Wang et al. 2002).

\section{Histochemical detection of AP activity}

Uterine cryosections $(12 \mu \mathrm{m})$ were fixed in cold $4 \%$ paraformaldehyde solution in PBS and incubated with 5-bromo-4-chloro3-indolyl phosphate/nitro blue tetrazolium (BCIP/NBT) substrate solution (Sigma) for $1-2$ min at $37^{\circ} \mathrm{C}$. The histochemical reaction of AP was monitored under a stereomicroscope. Sections were rinsed in PBS and mounted in GVA solution. As a negative control, some slides with mounted uterine sections were microwaved (highest power level) for 5-10 min in PBS prior to incubation with substrate solution (Jones et al. 1974). To determine levamisole-sensitive and -insensitive forms of uterine AP isozymes, some slides were incubated with levamisole (TNAP inhibitor: $20 \mathrm{mg} / \mathrm{ml}$ ) for $4 \mathrm{~h}$ at room temperature prior to addition of substrate solution. Sections were not counterstained in order to avoid obscuring phosphatase activity.

\section{Cell-specific localization of gIAP by immunohistochemistry}

Uterine cryosections were fixed in $10 \%$ buffered formalin and then stained with rabbit polyclonal gIAP antibody at a dilution of 1:250 in PBS as described previously 
(Narisawa et al. 2007). The specificity of the staining was confirmed with antibody replaced with equal amounts of nonimmune rabbit IgG. Sections were post-stained with hematoxylin and photographed.

\section{Lipopolysaccharide-dephosphorylation assay by uterine homogenates and recombinant TNAP and gIAP proteins}

Lipopolysaccharide (LPS)-dephosphorylating activity present in homogenates of day 1 uteri and day 7 implantation sites was assayed according to the protocol described by Goldberg et al. (2008). Briefly, tissue lysates equivalent to $2 \mu \mathrm{g}$ protein were added into a $100 \mu \mathrm{l}$ reaction buffer $(50 \mathrm{mM}$ Tris- $\mathrm{HCl}$ (pH 7.6), $150 \mathrm{mM} \mathrm{NaCl}, 1 \mathrm{mM} \mathrm{MgCl}_{2}$, and $20 \mu \mathrm{M} \mathrm{ZnCl}_{2}$ ) with/ without LPS $(0.25 \mathrm{mg} / \mathrm{ml}$; Escherichia coli (serotype 055:B5) from Sigma (cat. \# L2880)) followed by incubation at $37^{\circ} \mathrm{C}$ for $3 \mathrm{~h}$. As negative controls, heat-inactivated $\left(95^{\circ} \mathrm{C}\right.$ for $1 \mathrm{~h}$ ) tissue lysates were added to the reaction mixture. To confirm uterine AP isozyme is involved in LPS dephosphorylation, uterine lysates were incubated with levamisole $(5 \mathrm{mM})$ on ice for $1 \mathrm{~h}$ prior to their addition to the reaction buffer. To detect $\mathrm{Pi}$ released from LPS, malachite green solution (1:4) was added for $10 \mathrm{~min}$ and activity was then determined from spectrophotometric absorbance readings (650 nm wave length) taking into account the background readings. Each assay was performed in triplicate.

Using the above-described method, levamisole sensitivity toward the LPS-dephosphorylating activity of recombinant TNAP and gIAP proteins was also determined (Narisawa et al. 2007). LPS hydrolysis by TNAP or gIAP in control groups was considered as $100 \%$.

\section{Histochemical detection of LPS dephosphorylation at cellular sites of AP production and activity}

To identify LPS dephosphorylation sites in the uterus, cryostat cut uterine sections from cyclic and early pregnant (days 1-8) uteri were fixed in formalin-Macrodex for $10 \mathrm{~min}$ and incubated with Tris/maleic acid buffer ( $\mathrm{pH}$ 7.6) containing $\mathrm{MgSO}_{4}$ and $\mathrm{Pb}\left(\mathrm{NO}_{3}\right)_{2}$ with or without LPS $(3.2 \mathrm{mg} / \mathrm{ml})$ for $2 \mathrm{~h}$ at room temperature. To ascertain uterine TNAP and gIAP involved in LPS dephosphorylation, sections were incubated with levamisole $(5 \mathrm{mM})$ at $37^{\circ} \mathrm{C}$ for $4 \mathrm{~h}$ prior to addition of reaction buffer with LPS. Slides were next washed with water, incubated with $\mathrm{Na}_{2} \mathrm{~S}(2 \%)$ for $30 \mathrm{~s}$, washed with water, post-stained with hematoxylin, dehydrated with ascending strengths of alcohol, washed in xylene, and mounted with Distrene, Plasticiser, Xylene (DPX; Bentala et al. 2002). Uterine sites of dark brown lead sulfide deposits were examined under bright field.

\section{Statistical analysis}

Statistical analysis was performed on all LPS dephosphorylation sites and real-time PCR data using the Student's t-test or one-way ANOVA followed by Tukey's test. Statistical significance was declared when $P$ value $\leq 0.05$. Data are presented as means \pm s.D. or \pm S.E.M.

\section{Results}

\section{Akp2 and Akp6 isozyme genes in the hamster uterus}

PCR was used to detect transcripts of Akp2, Akp3, Akp5, and $A k p 6$ in day 1 uterus and day 6 implantation sites. Among the $A k p 2, A k p 3, A k p 5$, and Akp6 genes, the uterus of the hamster expressed the TNAP isozyme gene Akp2 and the gIAP isozyme gene Akp6. Akp2 and Akp6 mRNAs were expressed in both the day 1 uterus and day 6 implantation sites (Fig. 1). The transcript of the Akp3 gene that encodes dIAP was not expressed in any hamster tissues used in this study but was expressed in the mouse intestine (mouse data not shown). The transcript of the Akp5 gene that encodes EAP was only detected in the hamster blastocyst.

\section{Akp2 and Akp6 mRNA expression and total AP activity showed cyclic variations in the uterine luminal epithelium during the estrous cycle}

To test the cellular source of the Akp2 and Akp6 genes in the non-pregnant uterus, in situ hybridization study was performed on uteri obtained from four stages of the estrous cycle. Endometrial expression of both genes was primarily observed in cells of the luminal epithelium (LE) and showed cyclic variations. The diestrous and proestrous uterine sections showed strong Akp2 mRNA expression in the LE, and thereafter, the $A k p 2$ expression from the uterine LE was gradually reduced from the proestrous day to the metestrous day (Fig. 2A). Uterine expression of $A k p 6$ mRNA was also strong in the LE of the diestrous, proestrous, and estrous days with reduced expression in the metestrous day (Fig. 2B). Expression of Akp2 and Akp6 mRNAs above the background level was not

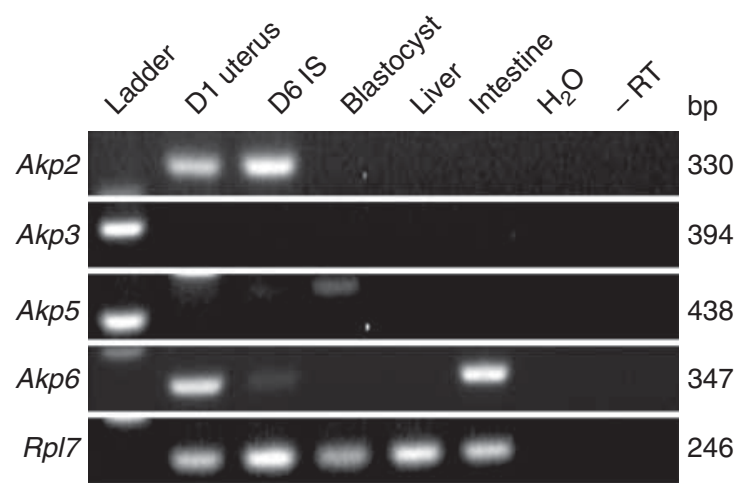

Figure 1 Expression of AP isozyme genes in the hamster uterine tissues. RT-PCR-amplified products of Akp2, Akp3, Akp5, and Akp6 in day 1 uteri, day 6 implantation site (D6 IS), blastocysts, liver, and intestine of hamsters. Water and DNase1-treated RNAs (D6 IS for Akp2; blastocysts for Akp5; and intestine for Akp6) without RT (-RT) were used as negative controls. Rpl7 was used as a constitutive gene control. These experiments were performed three times with three independent samples with similar results. 
A
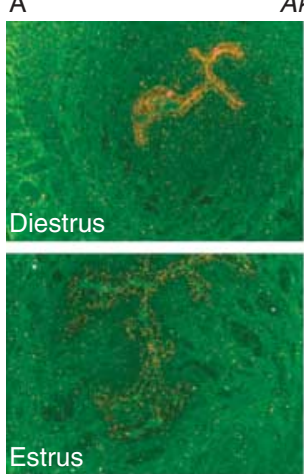

B

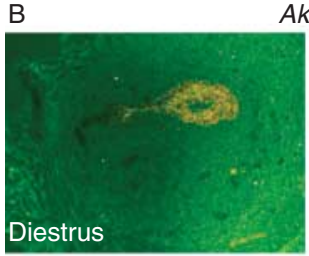

Akp6
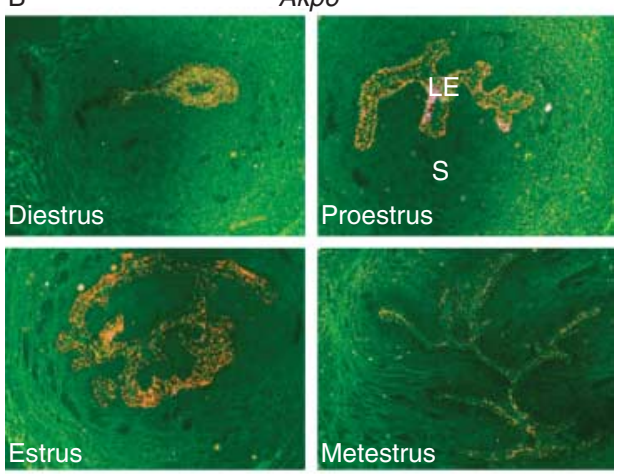

C

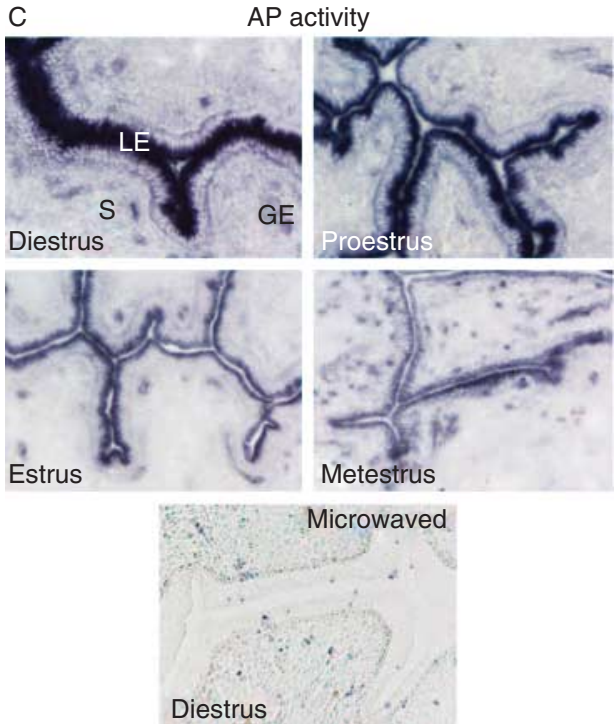

Figure 2 Cyclic changes of the uterine AP isozyme gene expression and total AP activity. Uterine cross sections were processed to demonstrate cyclic variations of $A k p 2$ (A) and $A k p 6$ (B) mRNA expression and total AP activity (C) during the estrous cycle. GE, glandular epithelium; LE, luminal epithelium; S, stroma. (A) Akp2 mRNA expression by in situ hybridization. Photographs were captured under dark field at $40 \times$ magnification ( $n=3 /$ day of the estrous cycle). (B) Akp6 mRNA expression by in situ hybridization. Photographs were captured under dark field at $40 \times$ magnification ( $n=3$ /day of the estrous cycle). (C) Total AP activity by histochemistry using BCIP/NBT solution. Photographs were captured under bright field at $200 \times$ magnification $(n=3 /$ day of the estrous cycle). Specificity of AP staining in sections from diestrous uteri was demonstrated by destroying endogenous enzyme activity through microwave heating. observed in cells of the glandular epithelium, stroma, and myometrial layers in any day of the estrous cycle.

In agreement with luminal epithelial expression of mRNAs of $A k p 2$ and Akp6, AP activity was also primarily observed in cells of the uterine LE (Fig. 2C). A few AP-positive cells were seen in the stromal compartment, but their identities were not determined in this study. AP activity appeared to be primarily localized in the apical cell surface layer of the LE. AP activity in the uterine LE was strong in uterine sections from the diestrous and proestrous days, and thereafter, its activity from the uterine LE gradually reduced from the proestrous day to metestrous day (Fig. 2C). These cyclic variations in the pattern of luminal epithelial AP activity were positively correlated with epithelial expression patterns of $A k p 2$ and Akp6 mRNAs in cyclic uteri. The observed alterations in AP isozyme gene expression and total AP activity in the uterine LE during the estrous cycle are indicative of modulation by steroid hormones.

\section{Induction of luminal epithelial Akp2 by $P_{4}$ and Akp6 by both $P_{4}$ and $E_{2}$ in ovariectomized hamsters}

Using the ovariectomized hamster model, we next examined whether Akp2 and Akp6 expression in the ovariectomized uterus is regulated by steroid hormones in the same manner as observed in the cyclic uterus. No detectable in situ hybridization signal for Akp2 or Akp6 mRNAs was observed in any uterine cell types of ovariectomized animals treated with oil. Compared with oil-injected controls, the $\mathrm{E}_{2}$-treated ovariectomized hamster uterus failed to show any change in Akp2 mRNA expression by $6 \mathrm{~h}$, but exhibited a slight increase, albeit with a lower intensity, in luminal epithelial $A k p 2$ expression at $12 \mathrm{~h}$ followed by a decline to the control level at $24 \mathrm{~h}$ (Fig. 3A). By contrast, we noted a gradual increase in the expression of Akp6 mRNA in luminal epithelial cells from 6 to $24 \mathrm{~h}$ after $\mathrm{E}_{2}$ treatment when compared with oil-injected controls (Fig. 3B). When ovariectomized hamsters were treated with $\mathrm{P}_{4}$ alone, increased Akp2 and Akp6 mRNA expression in uterine luminal epithelial cells was noted by $6 \mathrm{~h}$. Thereafter, mRNA expression of both these genes in the LE remained elevated until $24 \mathrm{~h}$ post-injection (Fig. $3 \mathrm{~A}$ and $\mathrm{B}$ ). The combined $E_{2} / P_{4}$ treatment showed a synergistic effect on $A k p 6$, but not on Akp2, mRNA expression. Cells of the uterine gland, stroma, and myometrium showed no specific autoradiographic signals for $A k p 2$ and $A k p 6$ in either $\mathrm{P}_{4^{-}}$or $\mathrm{E}_{2}$-treated ovariectomized hamsters (Fig. 3A and B). The in situ hybridization results at the 12-h time point were independently confirmed by real-time PCR. The levels of $A k p 2$ (Fig. 3C) and Akp6 (Fig. 3D) mRNAs after hormone treatment corroborated with the patterns of expression of Akp2 and Akp6 as observed by in situ hybridization. 

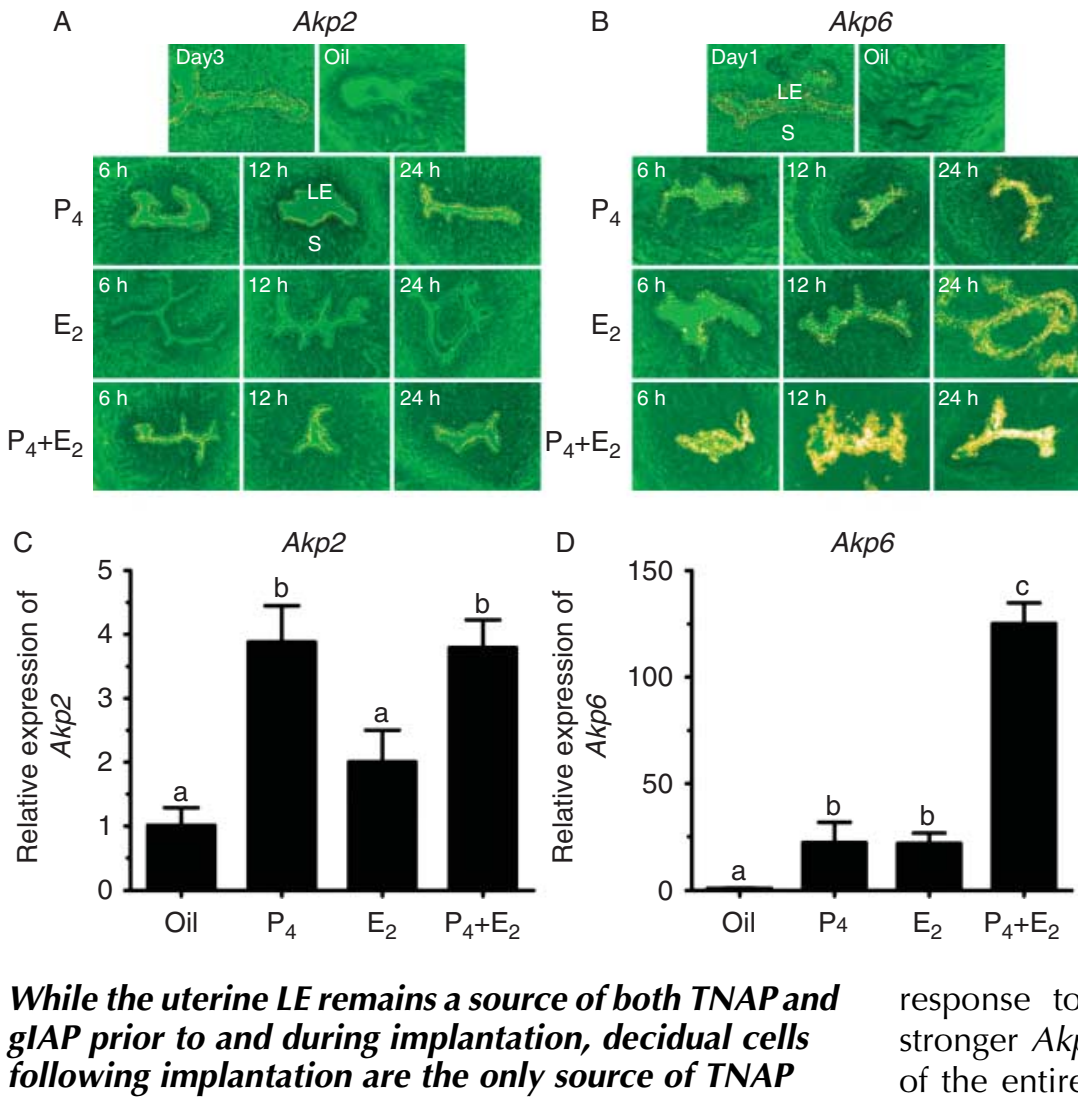

\section{While the uterine LE remains a source of both TNAP and gIAP prior to and during implantation, decidual cells following implantation are the only source of TNAP}

Because hamster uterine $A k p 2$ and $A k p 6$ expressions are regulated by steroid hormones, we then examined localization and expression patterns of $A k p 2$ and $A k p 6$ mRNAs by in situ hybridization and gIAP protein (the product of $A k p 6$ ) by immunohistochemistry in the uterus during the preimplantation, implantation, and decidualization periods (days 1-8 of pregnancy) (Fig. 4A, B, and C). Cell-specific localization of the Akp2 product TNAP was not performed as commercially available TNAP antibodies failed to recognize hamster TNAP protein. During the preimplantation period (days 1-4 morning), the day 1 uterus showed moderate expression of $A k p 2$ and Akp6 mRNAs only in cells of the LE. Both the Akp2 (Fig. 4A) and Akp6 (Fig. 4B) mRNA signals were then reduced in the day 2 uterus. However, Akp2 and Akp6 mRNA expression in the uterine LE became stronger on days 3 and 4 of pregnancy than on days 1 and 2 of pregnancy. Uterine myometrial and stromal cells showed little or no expression of Akp2 and Akp6 mRNAs from days 1 to 4 of pregnancy. Immunoreactivity of gIAP was detected in uterine LE cells, and gIAP protein expression patterns were very similar to $A k p 6$ mRNA expression patterns in preimplantation uteri. The expression of gIAP protein was lower on day 2 than on day 1 of pregnancy but showed an increase on days 3 and 4 of pregnancy (Fig. 4C). We next conducted studies to determine whether their expression patterns at the uterine implantation site show any cell specificity in
Figure 3 Steroid hormonal regulation of uterine AP isozyme gene expression in ovariectomized hamsters. Vehicle- and $\mathrm{E}_{2}$ - and/or $\mathrm{P}_{4}$-treated animals ( $n=3 /$ treatment group) were killed at 6, 12, and $24 \mathrm{~h}$ after injection. Uterine cross sections from ovariectomized hamsters treated with vehicle (sesame seed oil), $E_{2}, \mathrm{P}_{4}$, or $\mathrm{E}_{2}$ plus $\mathrm{P}_{4}$ were processed to determine hormonal regulation of Akp2 (A) and Akp6 (B) mRNA expression by in situ hybridization. LE, luminal epithelium; $S$, stroma. Photographs were captured under dark field at $100 \times$ magnification. Total RNAs were extracted from vehicle- and hormone-treated groups at the 12-h time point and subjected to real-time PCR for Akp2 (C) and Akp6 (D). Different letters on top of bars show a significant difference $(P<0.05)$ among these groups. Data are shown as mean \pm s.D.

response to implantation. On day 5 of pregnancy, stronger Akp2 mRNA expression was observed in cells of the entire LE away from the implantation site when compared with its expression in luminal epithelial cells surrounding the implanted embryo (Fig. 4A). By contrast, Akp6 mRNA showed strong expression in the LE cells surrounding the implanted embryo as well as in cells of the LE immediately above the implantation chamber toward the mesometrial side and reduced expression in the LE cells further away from the implantation chamber (Fig. 4B). This unusual Akp6 mRNA expression in day 5 implantation sites led us to examine its expression pattern in implantation sites obtained from day 4 of pregnancy at $1800 \mathrm{~h}$ when the initial blastocyst-uterine attachment reaction occurs in hamsters (Reese et al. 2008). A similar pattern of Akp6 mRNA expression that was observed at the day 5 implantation site was also noted on the early day 4 implantation site (Fig. 4B). The cellular expression pattern of gIAP protein at days 4 and 5 implantation sites followed the similar expression pattern of Akp6 mRNA. Immunoreactive gIAP protein was primarily detected in the LE cells adjacent to the implanted blastocyst on the evening of day 4 and morning of day 5 (Fig. 4C).

As the early events of implantation induce transformation of uterine stromal cells into decidual cells, decidual cells surrounding the implantation chamber began to show $A k p 2$, but not $A k p 6$, mRNA expression at low levels on day 5 of pregnancy. However, Akp2 gradually showed stronger expression in the entire decidual zone surrounding the implanted embryo with 
A
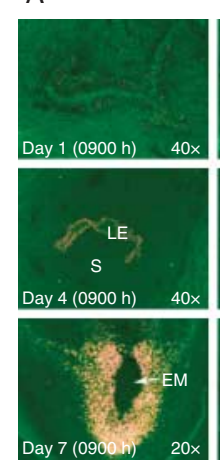

B
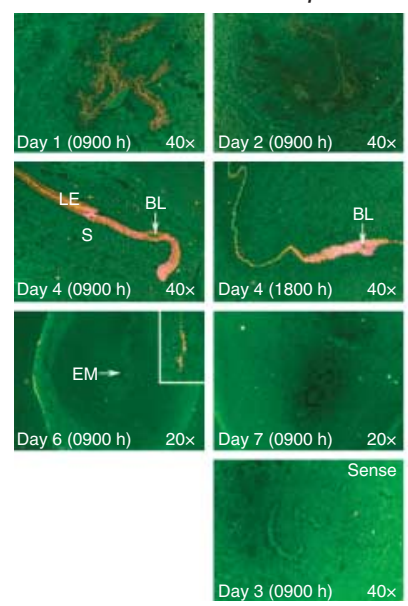

Akp2

Akp6
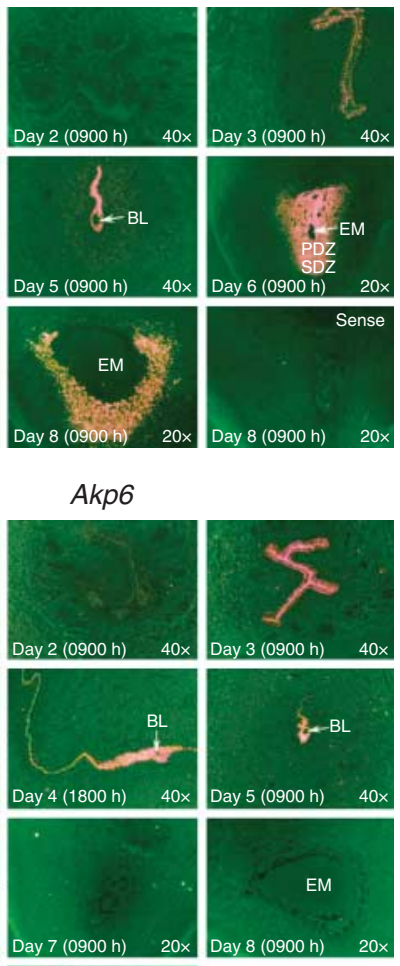

C

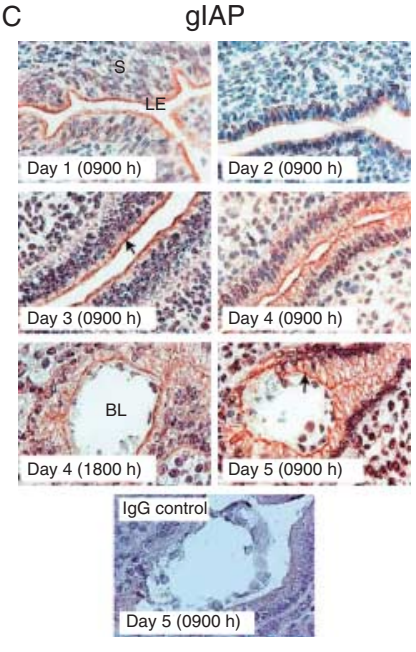

Figure 4 Event-specific change in the uterine cellspecific localization of AP isozyme genes and proteins during early pregnancy. Cross or longitudinal sections from day 1 to day 4 uteri and day 4 to day 8 implantation sites were processed to demonstrate cellspecific expression of Akp2 (A) and Akp6 (B) mRNAs and gIAP protein (C). BL, blastocyst; EM, embryo;

$\mathrm{LE}$, luminal epithelium; $\mathrm{PDZ}$, primary decidual zone; SDZ, secondary decidual zone. (A) Akp2 mRNA expression by in situ hybridization. Photographs were captured under dark field ( $n=3 /$ day of pregnancy). Sections hybridized with $A k p 2$ sense probes served as negative controls. (B) Akp6 mRNA expression by in situ hybridization. Photographs were captured under dark field ( $n=3$ /day of pregnancy). Longitudinal sections from day 4 morning $(0900 \mathrm{~h})$ uteri and day 4 evening $(1800 \mathrm{~h})$ implantation sites were used for hybridization. Inset shows higher magnification $(200 \times)$ picture. Sections hybridized with Akp6 sense probes served as negative controls. (C) Immunohistochemical detection of gIAP. Photographs were captured under bright field at $400 \times$ magnification ( $n=3$ or 4 /day of pregnancy). The specificity of immunostaining was confirmed by replacing primary antibody with non-immune rabbit IgG. Arrow indicates apical immunolocalization of gIAP. the progression of the implantation/decidualization process from days 6 to 8 of pregnancy (Fig. 4A). Embryos at the days 7 and 8 implantation sites showed low levels of $A k p 2$, but not Akp6, mRNA expression (Fig. 4A and B). Remaining luminal epithelial cells at the mesometrial side of the implantation site showed low levels of both Akp2 and Akp6 mRNA expression. These data suggested that while mRNAs for both the Akp2 and Akp6 isozyme genes and gIAP protein are expressed in uterine luminal epithelial cells, the Akp2 isozyme gene is specific for uterine decidual cells following implantation.

\section{Histochemical detection of uterine total AP activity and its isozyme-specific contributions during the preimplantation, implantation, and decidualization phases}

Having established that cellular Akp2 and Akp6 mRNAs showed event-specific expression in uterine cells prior to, during, and following implantation, we next investigated the total biochemical activity of uterine AP enzymes in the uterus during the preimplantation, implantation, and decidualization periods to correlate total AP activity patterns with the observed expression patterns of $A k p 2$ and Akp6 mRNAs. In addition, because of uterine expression of both the Akp2 and Akp6 gene products, histochemical examination of uterine AP activity was performed in the presence or absence of levamisole to differentiate levamisole-sensitive and levamisole-insensitive uterine total AP activity. Levamisole is a well-known and widely used uncompetitive inhibitor of the Akp2 gene product TNAP (Kozlenkov et al. 2004), but its sensitivity toward the activity of gIAP is unknown. As no specific inhibitor of gIAP has been reported, we assumed at this stage that the levamisole-insensitive AP activity in the uterine LE would be contributed by a product of an AP isozyme gene other than Akp2.

The results in Fig. $5 \mathrm{~A}$ and $\mathrm{B}$ showed that the total activity of uterine APs from days 1 to 4 of pregnancy correlates well with the combined expression patterns of both Akp2 and Akp6 mRNAs on these days. The results in Fig. 5B showed that levamisole failed to block complete activity of AP in uterine epithelial cells during the preimplantation period. The pattern of the levamisole-insensitive AP activity in the preimplantation uterus correlates well with the Akp6 mRNA and gIAP protein expression pattern on these days. Thus, we predicted that the remaining levamisole-insensitive uterine AP activity in the preimplantation uterus is due to the presence of gIAP protein. 


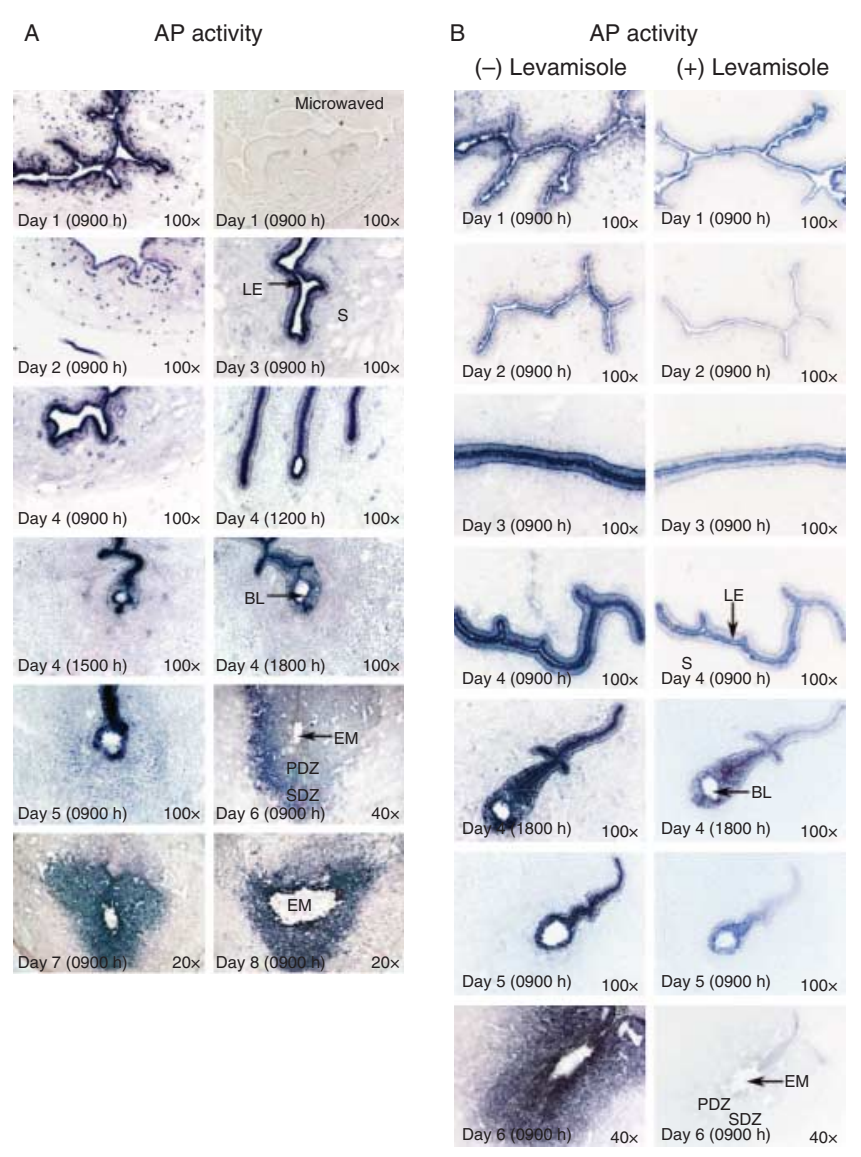

Figure 5 Total and levamisole-sensitive and -insensitive AP activities in the peri-implantation hamster uterus. Cross sections from days 1 to 4 uteri and days 4 to 8 implantation sites were processed to demonstrate cell-specific localization of total AP (A) and levamisole-insensitive AP (B) activities. Photographs were captured under bright field ( $n=3$ or 4/day of pregnancy). BL, blastocyst; EM, embryo; LE, luminal epithelium; PDZ, primary decidual zone; S, stroma; SDZ, secondary decidual zone. (A) Total APactivity in peri-implantation uteri (days 1-8) as determined by histochemistry. Specificity of AP staining in sections from day 1 uteri was demonstrated by destroying endogenous enzyme activity through microwave heating. (B) Residual AP (levamisoleinsensitive) activity after levamisole treatment in the peri-implantation (days 1-6) uterine sections.

We next investigated the total AP activity pattern as well as levamisole sensitivity of APs at the initial period of implantation and during decidualization. The LE cells adjacent to and away from days 4 to 5 implantation sites showed strong AP activity (Fig. 5A and B). However, while levamisole treatment on sections from days 4 to 5 implantation sites eliminated the AP activity from the LE cells away from the implantation site, a large proportion of the total AP activity still persisted in LE cells surrounding the implanted blastocyst (Fig. 5B). This epithelial levamisole-insensitive AP activity pattern surrounding the implanted blastocyst corresponds to the expression pattern of $A k p 6$ mRNAs and gIAP protein. Together, these findings clearly show unique epithelial
gIAP protein expression and activity at the implantation site. Uterine stromal cells surrounding the implanted embryo begin to show AP activity early on day 5 of pregnancy. The entire decidual zone surrounding the implanted embryo showed strong AP activity from days 6 to 8 of pregnancy. In decidual cells, however, the AP activity pattern overlapped with only the Akp2 mRNA expression pattern on these cells. Furthermore, when uterine sections from day 6 implantation sites were pretreated with levamisole, the AP activity was considerably inhibited in luminal epithelial cells and completely abolished from cells of the day 6 decidua (Fig. 5B). These data suggested that while AP isozyme activities in uterine luminal epithelial cells are contributed by the TNAP and gIAP isozymes, AP activity in decidual cells following implantation is contributed by only the TNAP isozyme.

\section{Decidual Akp2 and TNAP activity is not influenced by the implanted blastocyst}

In an attempt to examine whether expression of $A k p 2$ mRNA and TNAP activity in decidual tissues following implantation is solely a function of the implanted blastocyst, Akp2 mRNA and TNAP activity was checked in sections obtained from day 6 decidual tissues induced by the embryo (decidum) or suture (deciduomata). Akp2 mRNA (Fig. 6A) and TNAP activity (Fig. 6B) were noted in sections from both the decidum and deciduomata. However, the intensity of Akp2 mRNA and AP activity was stronger in the decidum than in the deciduomata. APactivity in cells of both the decidum and deciduomata was levamisole sensitive (Fig. 6B). These results suggest that decidual expression of the Akp2 gene and TNAP activity is not exclusively regulated by the embryo. An additional noticeable finding in this study was that the remaining epithelial layer at the implantation site and suture-induced decidual area and intact epithelial cells at the mesometrial side were AP positive and levamisole insensitive.

\section{Uterine AP possessed the property of LPS detoxification by dephosphorylation}

To explore the role of hamster uterine AP in LPS dephosphorylation, biochemical AP activity was measured in homogenates from the day 1 uterus and day 7 implantation sites using LPS as a substrate. Tissue homogenates in the presence of LPS showed a significant increase in inorganic phosphate $(\mathrm{Pi})$ release compared with the control group in which LPS was not added. When enzyme activity of uterine homogenates was inactivated at $95^{\circ} \mathrm{C}$, no considerable change in $\mathrm{Pi}$ release was observed after LPS addition when compared with the control group without LPS (Fig. 7A and B). In order to define the uterine-specific APs that are responsible for the LPS dephosphorylation, levamisole 
A

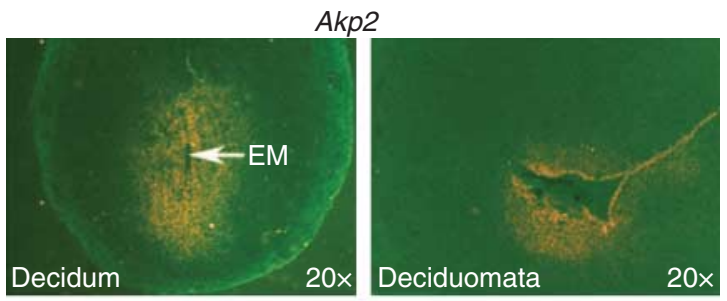

B

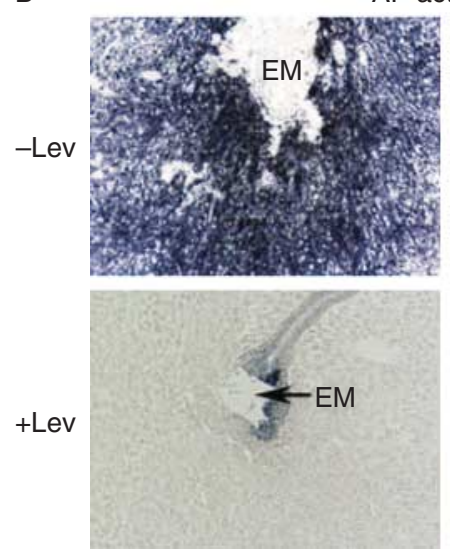

Decidum (100x)
AP activity

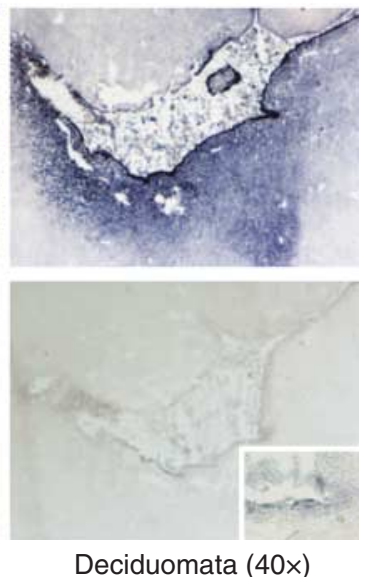

Figure 6 Expression of $A k p 2$ mRNA (A) and total AP activity (B) in the day 6 embryo-induced decidum and suture-induced deciduomata. EM, embryo. (A) Expression of Akp2 mRNA by in situ hybridization. Photographs were captured under dark field $(n=3)$. (B) Histochemical staining of AP activity in the presence and absence of levamisole (Lev). Photographs were captured under bright field $(n=4)$. Inset shows higher magnification $(200 \times)$ of levamisole-insensitive AP activity in residual epithelial cells.

(inhibitor of TNAP) was added into homogenates prior to and during incubation with LPS. While levamisole entirely blocked the Pi release from LPS by homogenates of day 7 implantation sites (Fig. 7B), it was only partially effective in inhibiting $\mathrm{Pi}$ release from LPS by day 1 uterine homogenates (Fig. 7A). The day 1 uterine LPS-dephosphorylating effect that was not blocked by levamisole treatment indicated that this fraction of the remaining uterine AP activity is insensitive to levamisole. At this point, it is unclear whether the residual day 1 uterine LPS dephosphorylation activity is due to the presence of gIAP as it is not known whether gIAP activity is sensitive or insensitive to levamisole. Thus, an LPS hydrolysis assay was performed using recombinant TNAP and gIAP proteins in the presence or absence of levamisole (Fig. 7C). The majority of the observed TNAP activity $(99.95 \%)$ was inhibited by levamisole while gIAP activity was partially (32.08\%) affected by levamisole. Together, our data suggested that TNAP is the primary AP responsible for LPS dephosphorylation at the day 7 implantation sites of the hamster. However, the day 1 uterine AP responsible for LPS dephosphorylation was partially contributed by TNAP as well as gIAP.

\section{LPS dephosphorylation was detected at uterine cellular sites of the AP isozyme mRNA expression and activity}

After establishing LPS dephosphorylation biochemically by uterine APs, we examined histochemically the sites of LPS dephosphorylation in the cyclic, preimplantation, and post-implantation uterus. Staining of sections from cyclic uteri, days 1 and 3 of preimplantation uteri, and implantation sites from days 5 to 7 of post-implantation uteri for AP activity at $\mathrm{pH} 7.6$ using LPS as a substrate yielded a pattern corresponding with the pattern and cell-specific localization of AP activity as demonstrated using the substrate BCIP at pH 9.5 (Fig. 8). Control sections incubated in the buffer without LPS exhibited no staining. Uterine sections from four stages of the cycle (Fig. 8A), and days 1 and 3 of pregnancy (Fig. 8B), displayed lead sulfide precipitates in the apical surface of the LE cells in the presence of LPS. Parallel to AP activity observed during the cycle using BCIP (Fig. 2), the LE cells of the diestrous uterus showed stronger LPS dephosphorylation than the uterine LE cells from the rest of the cycle. Similarly, parallel to AP activity seen in the preimplantation uteri using BCIP (Fig. 5), day 3 uterine LE cells showed stronger LPS dephosphorylation than day 1 uterine LE cells. While uterine LE cells surrounding as well as away from the day 5 implantation sites showed dark brown staining, only cells of the decidua of day 7 implantation site exhibited brown staining in the presence of LPS. The results presented in the lower panel of Fig. 8B showed that levamisole failed to block complete activity of AP in uterine epithelial cells in sections from days 1 to 3 of pregnancy. Similarly, the residual AP activity was also observed in the LE cells surrounding and immediate to the day 5 implantation sites in the presence of levamisole. The remaining levamisoleinsensitive AP activity in these sections may be indicative of LPS dephosphorylation by gIAP. However, levamisole treatment on sections from the day 7 implantation site completely abolished LPS dephosphorylation from the decidual cells, suggesting occurrence of LPS dephosphorylation by TNAP in these cells.

\section{Discussion}

The experiments described in this study established at the molecular and cellular levels that cells of the hamster uterine LE express two AP isozyme genes Akp2 and Akp6 that encode TNAP and gIAP respectively. These findings support a previous study that emphasized the existence of levamisole-sensitive TNAP and levamisole-insensitive IAP activities in the uterus of the ovariectomized hamster (Grusheikaia \& Loktionov 1980). Our findings also agree with their observations that the intestinal type of AP isozyme is primarily expressed in uterine epithelial cells. However, while their study using only histochemical techniques claimed TNAP isozyme expression in stromal cells, our combined studies involving cellspecific localization of $A k p 2$ mRNAs and TNAP activity 
clearly showed TNAP isozyme expression in uterine epithelial, but not in stromal, cells. Expression of uterine Akp6 seems to be specific in the hamster as studies in the mouse uterus showed expression of only Akp2 (Pollard et al. 1990).

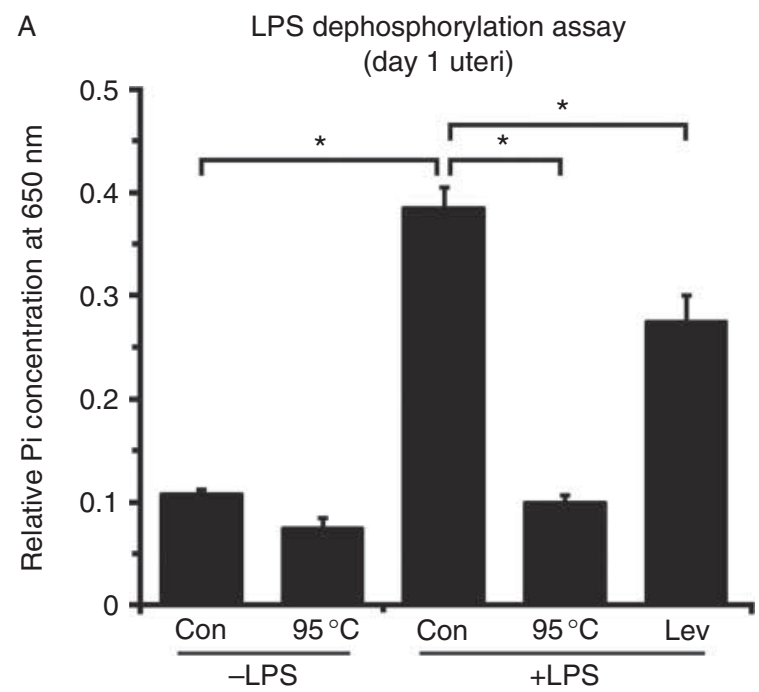

LPS dephosphorylation assay (day 7 implantation sites)

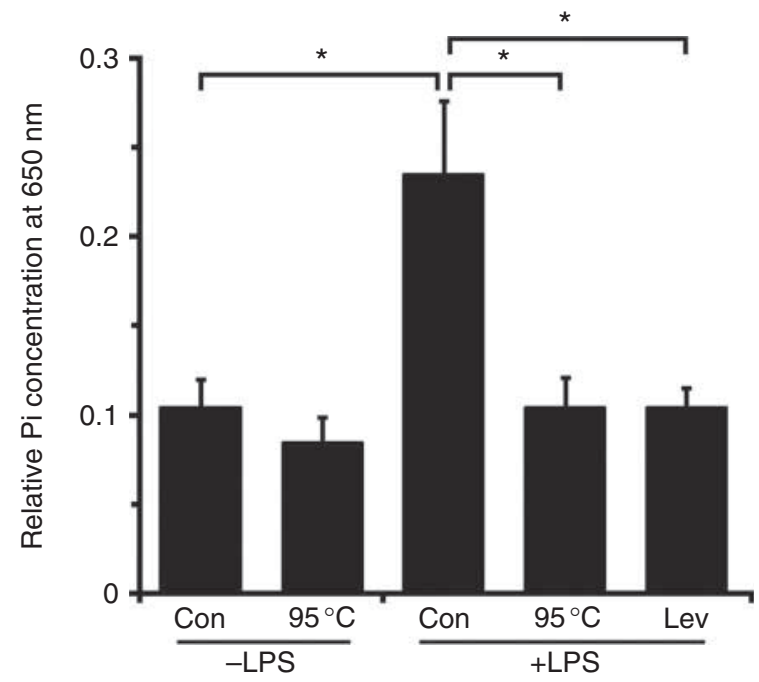

C

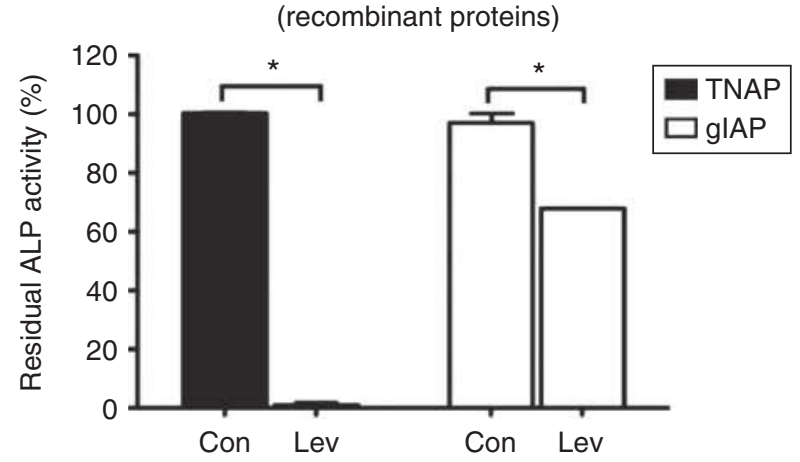

Our results on Akp2 and Akp6 mRNA expressions and total AP activity in the uterus of cyclic hamsters showed cyclic variations suggesting regulation of epithelial AP isozymes by steroid hormones. The diestrous uterus in hamsters is influenced by increased plasma levels of $\mathrm{P}_{4}$ on the metestrous day. However, ovulation and sexual receptivity in this species are characteristics of the estrous stage under the surge of circulating plasma $P_{4}$ and estrogen that occurs in the afternoon of the proestrous day (Lukaszewska \& Greenwald 1970, Baranczuk \& Greenwald 1973). Thus, the increase in the luminal epithelial Akp2 message on the diestrous and proestrous days when compared with the estrous and metestrous day is coincident with the influence of $\mathrm{P}_{4}$ on the uterus. However, the strong expression of $A k p 6$ message on the estrous day in addition to diestrous and proestrous day when compared with the metestrous day is suggestive of regulation by both $\mathrm{P}_{4}$ and estrogen. The pattern of uterine luminal epithelial total AP activity was positively correlated with epithelial $A k p 2$ and $A k p 6$ gene expression patterns in cyclic uteri. The predicted contributions of $\mathrm{P}_{4}$ and/or estrogen in the regulation of uterine Akp2 and Akp6 mRNA expressions during the estrous cycle were next ascertained by hormone replacement experiments in the ovariectomized hamsters. The regulation of $A k p 2$ mRNA expression in the uterus by $\mathrm{P}_{4}$ is confirmed, but no synergistic influence of combined treatment of $\mathrm{E}_{2}$ and $\mathrm{P}_{4}$ on $A k p 2$ was noticed. Induction of $A k p 2$ mRNA and TNAP activity by $\mathrm{P}_{4}$ has been demonstrated previously in human breast cancer cells (Di et al. 1991). As an earlier report in mice suggested regulation of the uterine TNAP activity by $\mathrm{E}_{2}$ (Manning et al. 1969), control of Akp2 gene expression by $\mathrm{P}_{4}$ in hamsters seems species specific. As expected from results of the estrous cycle, expression of Akp6 mRNA in the uterus of ovariectomized hamsters showed regulation by both $P_{4}$ and $E_{2}$ and the combined $P_{4} / E_{2}$ treatment showed a synergistic effect. This information partly agrees with a previous study in hamsters that

Figure 7 LPS dephosphorylation by day 1 uteri and day 7 implantation sites. LPS-dephosphorylating activity by homogenates from day 1 uteri (A), day 7 implantation sites (B), and recombinant TNAP and gIAP isozymes (C). (A) Biological LPS-dephosphorylating activities present in day 1 uterine homogenates. Levamisole (Lev) failed to totally inhibit LPS-dephosphorylating activities of day 1 uterine homogenates. Results were expressed as mean absorbance value \pm s.D. $(n=5)$. Data were analyzed using one-way ANOVA followed by Turkey's test $(*, P<0.05)$. (B) Biological LPS-dephosphorylating activities present in homogenates of day 7 implantation sites. Lev inhibited the major fraction of LPS-dephosphorylating activities of day 7 uterine homogenates. Results were expressed as mean absorbance value \pm s.D. $(n=5)$. Data were analyzed using one-way ANOVA followed by Turkey's test $(*, P<0.05)$. (C) Effect of Lev on the LPS dephosphorylation by recombinant TNAP and gIAP. LPS hydrolysis by TNAP and gIAP in control (Con) groups was considered as $100 \%$. Data were mean \pm s.E.M. of three different determinations (Student's $t$-test, $*, P<0.05$ ). 


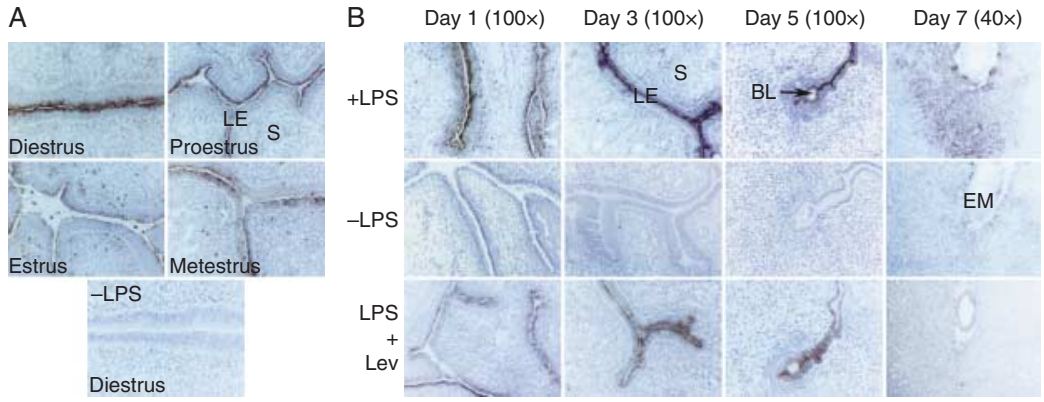

Figure 8 LPS dephosphorylation at uterine sites of AP production during the cycle and peri-implantation period. Histochemical localization of AP activity in sections from cyclic (A) and peri-implantation uteri (day 1, day 3 and implantation sites of days 5 and 7) (B) using LPS as a substrate. All sections were counterstained with hematoxylin. A dark brown staining indicated lead sulfide precipitates. Photographs were captured under bright field $(n=4)$. Control sections without LPS were completely negative. Residual stainings in levamisole (Lev)-treated sections from day 1 , day 3 , and day 5 uteri indicated Lev-insensitive gIAP activity. BL, blastocyst; EM, embryo; LE, luminal epithelium; S, stroma.

showed increased activity of the intestinal type of AP isozyme in the uterus of ovareictomized hamster treated with only benzestrol (Grusheikaia \& Loktionov 1980).

Previous studies have demonstrated that AP activity is associated with the differentiative state, but not the proliferative state, of epithelial cells (Wood et al. 2003, Marvin-Guy et al. 2008). Consistent with this view, we observed the lowest AP activity in day 2 epithelial cells when these cells were proliferating and strong APactivity in days 3 and 4 uterine epithelial cells when these cells were differentiating to support implantation (Zhang \& Paria 2006). We suggest that in the hamster as opposed to the mouse, in which AP activity in the preimplantation uterus gradually decreased from day 1 onward (Manning et al. 1969, Murdoch et al. 1978, Bucci \& Murphy 1995), uterine epithelial AP activity or mRNA expression patterns of $A k p 2$ and $A k p 6$ uphold the promise of useful markers for the receptive uterus. However, it is unknown what role TNAP and gIAP might play in uterine LE cells during the receptive state. Although a growing body of evidence supports their involvement in pathophysiological conditions like obstructive jaundice, rickets, hypophosphatasia, and intestinal inflammatory diseases (Narisawa et al. 1997, Goldberg et al. 2008, Millan et al. 2008, Ramasamy et al. 2011), neither the specific biological substrate(s) for AP isozymes nor the interrelationship of these isozymes is known. Luminal epithelial cells show apical plasma membrane alterations such as polarity changes and flattening of microvilli with reorganization of apical molecules during epithelial cell surface preparation for blastocyst attachment in a variety of species including the hamster, mouse, rabbit, camels, and human (Bucci \& Murphy 1995, tin-Ley 2000, Bagot et al. 2001). These changes in the surface of epithelial cells may be associated with phosphorylation/ dephosphorylation of proteins and phospholipids in their membrane lipid bilayer. Thus, our findings suggest that hamsters may utilize the AP activity in epithelial cells to support the phosphorylation status of the cell surface molecules that are helpful at the time of the uterine receptivity and blastocyst attachment. Regarding this possibility, it is known that several plasma membrane enzymes such as metalloproteinases and lipid-hydrolyzing enzymes are involved in alteration of cellular plasma membrane properties during the embryo-uterine attachment reaction (Giudice 1999) and sperm-egg fusion for fertilization (Boldt et al. 1988) respectively. However, we are not in a position to predict which AP isozyme (TNAP or gIAP) contributes the most to the establishment of uterine receptivity. The co-expression of both TNAP and gIAP in the luminal epithelial cells of the preimplantation uterus indicates that these two isozymes may play a compensatory role in the uterine LE. However, the differential expression of $A k p 2$ and Akp6 at the early implantation site of this species indicates that the uterus may favor the product of $A k p 6$ over $A k p 2$ to bring changes in epithelial surface morphology and biochemistry that are needed at the blastocyst attachment site.

Studies in the post-implantation sites from days 5 to 8 of pregnancy and suture-induced decidual cells in hamsters suggest that any local stimulus that has the ability to induce transformation of stromal cells to decidual cells is adequate to induce decidual TNAP expression. These findings support previous studies in mice that have considered TNAP as an indicator of stromal cell decidualization as strong TNAP activity is observed in cells of both the decidua and deciduomata (Manning et al. 1969). On the basis of these results, we suggest that decidual $A k p 2$ expression may only be associated with inflammatory aspects of normal implantation as stromal cell decidualization as a result of implantation or an other external stimulus has been considered as an inflammatory reaction (Bilinski et al. 1998). There is no information about the AP activity in the human decidua following implantation, although the presence of AP activity is reported in uterine predecidual cells during the secretory phase of the menstrual cycle (Wilson 1969). AP, along with Bmp2 and IL $11 R \alpha$, is a widely accepted decidual marker. Bmp2 and IL11R signaling at the implantation sites in mice 
have been demonstrated to be required for decidual development at the implantation site (Bilinski et al. 1998, Lee et al. 2007, Ramathal et al. 2010). Bmp2 and IL11R $\alpha$ are also potent $A k p 2$ mRNA and TNAP activityinducing agents (Suga et al. 2001, Kim et al. 2004). Thus, it is possible that AP mediates the actions of Bmp2 and IL11 signaling in decidua development. A direct role of AP in decidua formation and function is not yet identified in any species including mice as Akp2-null mice die prior to weaning due to skeletal defects and seizures (Waymire et al. 1995, Narisawa et al. 1997).

Several studies have identified that LPS is a substrate for AP (Bentala et al. 2002, Koyama et al. 2002, Beumer et al. 2003). LPS is a constituent of Gram-negative bacterial cell wall and elicits strong inflammatory responses in tissues. If uterine AP represents a true protective enzyme against LPS, it should be able to detoxify LPS by dephosphorylation, and uterine cells that express AP would be the sites of LPS dephosphorylation. In this study, we found that homogenates of day 1 uterus and day 7 implantation sites when incubated with LPS showed significant amount of $\mathrm{Pi}$ release, suggesting uterine AP activity in both days of pregnancy. However, while levamisole fully restrained the LPS dephosphorylation activity of day 7 implantation sites, it only reduced about $50 \%$ of LPS dephosphorylation activity of day 1 uterine homogenates. These observations suggest that while the day 1 uterus possesses both the levamisole-sensitive and -nonsensitive AP activities, the day 7 implantation sites only contain levamisolesensitive TNAP activity. This biochemical assay, however, did not indicate the site of LPS dephosphorylation in uterine cells. Results from our histochemical studies in cyclic and pregnant uteri using LPS as a substrate for AP activity at the physiological $\mathrm{pH}$ level showed the same pattern as the AP activity using the conventional substrate BCIP. Based on these findings, we inferred that uterine epithelial and decidual cells are the initial responding cells to endotoxin, and uterine AP isozymes have the potential to detoxify LPS at their site of expression.

In conclusion, we report that two AP isozymes TNAP and gIAP are expressed in the hamster uterus and they might be involved in the process of uterine receptivity, implantation, and decidualization. In addition, they may function as endotoxin detoxification molecules under normal physiological conditions as well as during uterine infection by pathogens. In this regard, it is worth noting that i) in vivo studies have demonstrated dephosphorylation of LPS by i.v. administration of exogenous AP (Chen et al. 2011) and ii) IAP treatment is beneficial to human ulcerative colitis and a mouse model of chronic colitis (Ramasamy et al. 2011). Thus, our studies raise the possibility that exogenous treatment with any AP that has strong catalytic activity could be used as a candidate drug for preventing uterine infection in general or during pregnancy and for lowering the risk of infection-induced pregnancy loss/defects.

\section{Declaration of interest}

The authors declare that there is no conflict of interest that could be perceived as prejudicing the impartiality of the research reported.

\section{Funding}

This work was supported by National Institutes of Health grants HD044741 and ARRA Administrative Supplements to HD044741. $\mathrm{Dr} \mathrm{H} \mathrm{Ni}$ is a recipient of visiting Scholar scholarship from China Scholarship Council to study abroad.

\section{Acknowledgements}

The authors thank Dr Klaas Poelstra (University of Groningen, The Netherlands) for kindly sharing the protocol for histochemical detection of LPS dephosphorylation by endogenous AP. The authors wish to express their appreciation to the members of the Collaborative Team of Interdisciplinary Research on Blastocyst Implantation (NICHD) for their encouragement during the course of this study.

\section{References}

Adamson GD \& Baker VL 2003 Subfertility: causes, treatment and outcome. Best Practice \& Research. Clinical Obstetrics \& Gynaecology 17 169-185. (doi:10.1016/S1521-6934(02)00146-3)

Aisemberg J, Vercelli C, Wolfson M, Salazar AI, Osycka-Salut C, Billi S, Ribeiro ML, Farina M \& Franchi AM 2010 Inflammatory agents involved in septic miscarriage. Neuroimmunomodulation 17 150-152. (doi:10.1159/000258710)

Bagot CN, Kliman HJ \& Taylor HS 2001 Maternal Hoxa10 is required for pinopod formation in the development of mouse uterine receptivity to embryo implantation. Developmental Dynamics 222 538-544. (doi:10.1002/dvdy.1209)

Baranczuk R \& Greenwald GS 1973 Peripheral levels of estrogen in the cyclic hamster. Endocrinology 92 805-812. (doi:10.1210/endo-923-805)

Bentala H, Verweij WR, Huizinga-Van der Vlag A, van Loenen-Weemaes AM, Meijer DK \& Poelstra K 2002 Removal of phosphate from lipid A as a strategy to detoxify lipopolysaccharide. Shock 18 561-566. (doi:10.1097/ 00024382-200212000-00013)

Bentin-Ley U 2000 Relevance of endometrial pinopodes for human blastocyst implantation. Human Reproduction 15 (Suppl 6) 67-73.

Beumer C, Wulferink M, Raaben W, Fiechter D, Brands R \& Seinen W 2003 Calf intestinal alkaline phosphatase, a novel therapeutic drug for lipopolysaccharide (LPS)-mediated diseases, attenuates LPS toxicity in mice and piglets. Journal of Pharmacology and Experimental Therapeutics 307 737-744. (doi:10.1124/jpet.103.056606)

Bilinski P, Roopenian D \& Gossler A 1998 Maternal IL-11R $\alpha$ function is required for normal decidua and fetoplacental development in mice. Genes and Development 12 2234-2243. (doi:10.1101/gad.12. 14.2234)

Boldt J, Howe AM \& Preble J 1988 Enzymatic alteration of the ability of mouse egg plasma membrane to interact with sperm. Biology of Reproduction 39 19-27. (doi:10.1095/biolreprod39.1.19)

Bucci M \& Murphy CR 1995 Alkaline phosphatase distribution in the plasma membrane of uterine epithelial cells is markedly altered during early pregnancy in the rat. Cell Biology International 19 921-928. (doi:10.1006/cbir.1995.1030) 
Chen KT, Malo MS, Beasley-Topliffe LK, Poelstra K, Millan JL, Mostafa G, Alam SN, Ramasamy S, Warren HS, Hohmann EL et al. 2011 A role for intestinal alkaline phosphatase in the maintenance of local gut immunity. Digestive Diseases and Sciences 56 1020-1027. (doi:10.1007/s10620010-1396-x)

Dehghani H, Narisawa S, Millan JL \& Hahnel AC 2000 Effects of disruption of the embryonic alkaline phosphatase gene on preimplantation development of the mouse. Developmental Dynamics 217 440-448. (doi:10.1002/(SICl)1097-0177(200004)217:4<440::AID-DVDY11>3. $0 . \mathrm{CO} ; 2-1)$

Di LD, Albertini A \& Zava D 1991 Progestin regulation of alkaline phosphatase in the human breast cancer cell line T47D. Cancer Research 51 4470-4475.

Finn CA \& Hinchliffe JR 1964 Reaction of the mouse uterus during implantation and deciduoma formation as demonstrated by changes in the distribution of alkaline phosphatase. Journal of Reproduction and Fertility 8 331-338. (doi:10.1530/jrf.0.0080331)

Giudice LC 1999 Potential biochemical markers of uterine receptivity. Human Reproduction 14 (Suppl 2) 3-16. (doi:10.1093/humrep/14. suppl_2.3)

Goldberg RF, Austen WG Jr, Zhang X, Munene G, Mostafa G, Biswas S, McCormack M, Eberlin KR, Nguyen JT, Tatlidede HS et al. 2008 Intestinal alkaline phosphatase is a gut mucosal defense factor maintained by enteral nutrition. PNAS 105 3551-3556. (doi:10.1073/pnas. 0712140105)

Goldenberg RL, Culhane JF, lams JD \& Romero R 2008 Epidemiology and causes of preterm birth. Lancet 371 75-84. (doi:10.1016/S01406736(08)60074-4)

Grusheikaia NV \& Loktionov AS 1980 Quantitative histochemical study of alkaline phosphatase isoenzymes in the uteri of ovariectomized golden hamsters during estrogenization. Biulleten' Eksperimental' noi Biologii $i$ Meditsiny 89 46-48.

Hahnel AC, Rappolee DA, Millan JL, Manes T, Ziomek CA, Theodosiou NG, Werb Z, Pedersen RA \& Schultz GA 1990 Two alkaline phosphatase genes are expressed during early development in the mouse embryo. Development 110 555-564.

Jones DJ, Medina MA, Ross DH \& Stavinoha WB 1974 Rate of inactivation of adenyl cyclase and phosphodiesterase: determinants of brain cyclic AMP. Life Sciences 14 1577-1585. (doi:10.1016/00243205(74)90168-4)

Keelan JA 2011 Pharmacological inhibition of inflammatory pathways for the prevention of preterm birth. Journal of Reproductive Immunology $\mathbf{8 8}$ 176-184. (doi:10.1016/j.jri.2010.11.003)

Kim YJ, Lee MH, Wozney JM, Cho JY \& Ryoo HM 2004 Bone morphogenetic protein-2-induced alkaline phosphatase expression is stimulated by Dlx5 and repressed by Msx2. Journal of Biological Chemistry 279 50773-50780. (doi:10.1074/jbc.M404145200)

Koyama I, Matsunaga T, Harada T, Hokari S \& Komoda T 2002 Alkaline phosphatases reduce toxicity of lipopolysaccharides in vivo and in vitro through dephosphorylation. Clinical Biochemistry 35 455-461. (doi:10.1016/S0009-9120(02)00330-2)

Kozlenkov A, Le Du MH, Cuniasse P, Ny T, Hoylaerts MF \& Millan JL 2004 Residues determining the binding specificity of uncompetitive inhibitors to tissue-nonspecific alkaline phosphatase. Journal of Bone and Mineral Research 19 1862-1872. (doi:10.1359/JBMR.040608)

Lee KY, Jeong JW, Wang J, Ma L, Martin JF, Tsai SY, Lydon JP \& DeMayo FJ 2007 Bmp2 is critical for the murine uterine decidual response. Molecular and Cellular Biology 27 5468-5478. (doi:10.1128/MCB. 00342-07)

Lukaszewska JH \& Greenwald GS 1970 Progesterone levels in the cyclic and pregnant hamster. Endocrinology 86 1-9. (doi:10.1210/ endo-86-1-1)

Malo MS, Alam SN, Mostafa G, Zeller SJ, Johnson PV, Mohammad N, Chen KT, Moss AK, Ramasamy S, Faruqui A et al. 2010 Intestinal alkaline phosphatase preserves the normal homeostasis of gut microbiota. Gut 59 1476-1484. (doi:10.1136/gut.2010.211706)

Manning JP, Steinetz BG \& Giannina T 1969 Decidual alkaline phosphatase activity in the pregnant and pseudopregnant rat. Annals of the New York Academy of Sciences 166 482-509. (doi:10.1111/j.1749-6632.1969. tb46416.x)

Marvin-Guy LF, Duncan P, Wagniere S, Antille N, Porta N, Affolter M \& Kussmann M 2008 Rapid identification of differentiation markers from whole epithelial cells by matrix-assisted laser desorption/ionisation time-of-flight mass spectrometry and statistical analysis. Rapid Communications in Mass Spectrometry 22 1099-1108. (doi:10.1002/ rcm.3479)

Millan JL 1990 Oncodevelopmental alkaline phosphatases: in search for a function. Progress in Clinical and Biological Research 344 453-475.

Millan JL 2006 Alkaline phosphatases: structure, substrate specificity and functional relatedness to other members of a large superfamily of enzymes. Purinergic Signalling 2 335-341. (doi:10.1007/s11302-0055435-6)

Millan JL, Narisawa S, Lemire I, Loisel TP, Boileau G, Leonard P, Gramatikova S, Terkeltaub R, Camacho NP, McKee MD et al. 2008 Enzyme replacement therapy for murine hypophosphatasia. Journal of Bone and Mineral Research 23 777-787. (doi:10.1359/jbmr.071213)

van Mourik MS, Macklon NS \& Heijnen CJ 2009 Embryonic implantation: cytokines, adhesion molecules, and immune cells in establishing an implantation environment. Journal of Leukocyte Biology 85 4-19. (doi:10.1189/jlb.0708395)

Murdoch RN, Kay DJ \& Cross M 1978 Activity and subcellular distribution of mouse uterine alkaline phosphatase during pregnancy and pseudopregnancy. Journal of Reproduction and Fertility 54 293-300. (doi:10.1530/jrf.0.0540293)

Nakano T, Inoue I, Koyama I, Kanazawa K, Nakamura K, Narisawa S, Tanaka K, Akita M, Masuyama T, Seo M et al. 2007 Disruption of the murine intestinal alkaline phosphatase gene Akp3 impairs lipid transcytosis and induces visceral fat accumulation and hepatic steatosis. American Journal of Physiology. Gastrointestinal and Liver Physiology 292 G1439-G1449. (doi:10.1152/ajpgi.00331.2006)

Narisawa S, Frohlander N \& Millan JL 1997 Inactivation of two mouse alkaline phosphatase genes and establishment of a model of infantile hypophosphatasia. Developmental Dynamics 208 432-446. (doi:10.1002/ (SICl)1097-0177(199703)208:3 < 432::AID-AJA13 > 3.0.CO;2-1)

Narisawa S, Huang L, Iwasaki A, Hasegawa H, Alpers DH \& Millan JL 2003 Accelerated fat absorption in intestinal alkaline phosphatase knockout mice. Molecular and Cellular Biology 23 7525-7530. (doi:10.1128/ MCB.23.21.7525-7530.2003)

Narisawa S, Hoylaerts MF, Doctor KS, Fukuda MN, Alpers DH \& Millan JL 2007 A novel phosphatase upregulated in Akp3 knockout mice. American Journal of Physiology. Gastrointestinal and Liver Physiology 293 G1068-G1077. (doi:10.1152/ajpgi.00073.2007)

Poelstra K, Bakker WW, Klok PA, Hardonk MJ \& Meijer DK 1997a A physiologic function for alkaline phosphatase: endotoxin detoxification. Laboratory Investigation 76 319-327.

Poelstra K, Bakker WW, Klok PA, Kamps JA, Hardonk MJ \& Meijer DK $1997 b$ Dephosphorylation of endotoxin by alkaline phosphatase in vivo. American Journal of Pathology 151 1163-1169.

Pollard JW, Jahan M \& Butterworth PJ 1990 Characterization and expression of uterine and placental alkaline phosphatases in the mouse. Journal of Reproduction and Fertility 89 735-742. (doi:10.1530/jrf.0. 0890735)

Ramasamy S, Nguyen DD, Eston MA, Alam SN, Moss AK, Ebrahimi F, Biswas B, Mostafa G, Chen KT, Kaliannan K et al. 2011 Intestinal alkaline phosphatase has beneficial effects in mouse models of chronic colitis. Inflammatory Bowel Diseases 17 532-542. (doi:10.1002/ibd.21377)

Ramathal CY, Bagchi IC, Taylor RN \& Bagchi MK 2010 Endometrial decidualization: of mice and men. Seminars in Reproductive Medicine 28 17-26. (doi:10.1055/s-0029-1242989)

Reese J, Wang H, Ding T \& Paria BC 2008 The hamster as a model for embryo implantation: insights into a multifaceted process. Seminars in Cell and Developmental Biology 19 194-203. (doi:10.1016/j.semcdb. 2007.11.001)

Suga K, Saitoh M, Fukushima S, Takahashi K, Nara H, Yasuda S \& Miyata K 2001 Interleukin-11 induces osteoblast differentiation and acts synergistically with bone morphogenetic protein- 2 in C3H10T1/2 cells. Journal of Interferon \& Cytokine Research 21 695-707. (doi:10.1089/ 107999001753124435)

Sweet RL 2012 Pelvic inflammatory disease: current concepts of diagnosis and management. Current Infectious Disease Reports 14 194-203. (doi:10.1007/s11908-012-0243-y) 
Wang X, Wang H, Matsumoto H, Roy SK, Das SK \& Paria BC 2002 Dual source and target of heparin-binding EGF-like growth factor during the onset of implantation in the hamster. Development 129 4125-4134.

Wang H, Luan L, Ding T, Brown N, Reese J \& Paria BC 2011 Dynamics of zonula occludens-2 expression during preimplantation embryonic development in the hamster. Theriogenology 76 678-686. (doi:10.1016/ j.theriogenology.2011.03.021)

Waymire KG, Mahuren JD, Jaje JM, Guilarte TR, Coburn SP \& MacGregor GR 1995 Mice lacking tissue non-specific alkaline phosphatase die from seizures due to defective metabolism of vitamin B-6. Nature Genetics 11 45-51. (doi:10.1038/ng0995-45)

Wilson EW 1969 Alkaline phosphatase in pre-decidual cells of the human endometrium. Journal of Reproduction and Fertility 19 567-568. (doi:10.1530/jrf.0.0190567)
Wood SR, Zhao Q, Smith LH \& Daniels CK 2003 Altered morphology in cultured rat intestinal epithelial IEC- 6 cells is associated with alkaline phosphatase expression. Tissue \& Cell 35 47-58. (doi:10.1016/S00408166(02)00103-9)

Zhang Q \& Paria BC 2006 Importance of uterine cell death, renewal, and their hormonal regulation in hamsters that show progesterone-dependent implantation. Endocrinology 147 2215-2227. (doi:10.1210/en.20051555)

Received 12 April 2013

First decision 7 May 2013

Revised manuscript received 31 July 2013

Accepted 8 August 2013 